\title{
Transferrin levels in antenatal women
}

\author{
Stephen S ${ }^{1}$, Samatha $\mathbf{P}^{2}$ \\ ${ }^{1}$ Dr.Sherin Stephen, Professor and Head, Department of Biochemistry, Academy of Medical Sciences, Pariyaram, \\ Kannur, Kerala, ${ }^{2}$ Dr Samatha P, M Sc Biochemistry student, Department of Biochemistry, Academy of Medical \\ Sciences, Pariyaram, Kannur, Kerala, India
}

Address for Correspondence: Dr. Sherin Stephen, Professor \& Head, Department of Biochemistry, Academy of Medical Sciences, Pariyaram, Kannur, Kerala, Email:sherin.stephen@rediffmail.com

\begin{abstract}
Introduction: During pregnancy, hemodilution leads to reduced hemoglobin, iron and ferritin concentration with increase in total iron binding capacity. Iron deficiency anemia is an important risk factor in pregnancy, attributing to $16 \%$ of all maternal deaths in India. Transferrin saturation is considered as the best marker of the iron supply for erythropoiesis. The aim of the study is to evaluate the levels of transferrin in antenatal women as a risk factor for iron deficiency anemia. The specific objectives are to find out comparison and correlation of the parameters used in the study. Methods: The present study group consists of 100 patients and 25 controls. Serum transferrin, total iron finding capacity and hemoglobin levels were investigated. Serum iron binding capacity and transferring levels were estimated by Ferrozine methods and hemoglobin by Cyanmethphotometric method. Results: The mean levels of transferrin in the patients in first trimester were $2.51 \pm 0.074 \mathrm{~g} / \mathrm{L}$, second trimester $2.87 \pm 0.058 \mathrm{~g} / \mathrm{L}$ and $2.16 \pm 0.72 \mathrm{~g} / \mathrm{L}$ in controls, which was statistically significant. The levels of total iron binding capacity in patients in the three trimesters were $358.36 \pm$ $10.73 \mu \mathrm{g} / \mathrm{dl}, 409.53 \pm 7.91 \mu \mathrm{g} / \mathrm{dl}$ and $471.57 \pm 12.10 \mu \mathrm{g} / \mathrm{dl}$ when compared to $308.48 \pm 10.09 \mu \mathrm{g} / \mathrm{dl}$ in controls and was statistically significant. Conclusion: The hemoglobin levels decreased significantly during each trimester than controls along with significant $\mathrm{P}$ values in second and third trimesters. Hence estimating the level of transferrin can be used as a marker for assessing iron deficiency anemia in pregnancy.
\end{abstract}

Key Words: Transferrin, Total iron binding capacity, Hemoglobin, Iron deficiency anemia.

\section{Introduction}

The assessment of nutritional status for iron during pregnancy in important because of the frequency with which deficiency of iron leads to the development of anemia in pregnancy [1]. If iron stores are reduced to the point of depletion of the reticulo endothelial iron, the subsequent events are a decrease in serum iron and an increase in serum iron binding capacity, leading to a decrease in percentage saturation of transferrin. This change in erythropoiesis is first manifested as transient development of normocytic anemia which is followed by hypochromic microcytic anemia of iron deficiency [2]. Transferrin is the non heme iron binding glycoprotein, major function of which is to transport iron to reticuloendothelical cells and bone marrow, to reach the immature red cells finally [3].
The physiological changes during pregnancy include expansion of plasma volume, increased erythropoiesis and increased demands of fetoplacental units for iron [4]. The values of total iron binding capacity in both iron supplemented and non supplemented women during pregnancy increased with increasing gestation, but the values are greater in those women who did not receive iron supplementation. Thus, there is definite effect on the levels of transferrin in pregnancy with further increase when there is concomitant iron depletion [5].

In the present study, transferrin was used as a marker to assess iron deficiency anemia in pregnancy and its correlation with total iron binding capacity and hemoglobin levels were also evaluated.

Manuscript received: $02^{\text {nd }}$ Feb 2016

Reviewed: $15^{\text {th }}$ Feb 2016

Author Corrected: $23^{\text {rd }}$ Feb 2016

Accepted for Publication: $3^{\text {rd }}$ March 2016 


\section{Materials and Methods}

The present study group consists of 100 patients who were pregnant and 25 normal healthy women of reproductive age were taken as controls. Blood samples were taken from the study group admitted in Academy of Medical Sciences, Pariyaram from April 2015 to September 2015 with their consent, after obtaining ethical clearance. Detailed baseline clinical data of each patient including age, height, weight, present and past clinical complaints obstetric, family and personal history were noted.
The following biochemical tests were done in patients and controls included in the study like estimation of serum transferrin, total iron binding capacity and hemoglobin. Investigations were done using Systronics UV-Visible spectrophotometer and CELL-DYN ${ }^{R} 3200$ fully automated analyzer. Serum total iron binding capacity (TIBC) and serum transferrin level were estimated by Ferrozine method. Statistical analysis is done using SPSS 17.0.

\section{Result}

In the study group 28 patients were in the first trimester and their mean age was $26.96 \pm 3.77,34$ were in second trimester with mean age of $28.44+4.50$ and 38 were in third trimester and their mean age was $26.37 \pm 3.48$. Mean age of 25 controls were $24.64+2.59$.

\section{Variation Between Patients and Control}

Table 1: Transferrin Levels (g/L)

\begin{tabular}{|l|c|c|c|c|}
\hline Group & N & Mean & Std Deviation & P value \\
\hline Patients & \multicolumn{3}{|l|}{} \\
\hline First trimester & 28 & 2.51 & 0.074 & 0.000. \\
\hline Second Trimester & 34 & 2.87 & 0.058 & 0.000 \\
\hline Third Trimester & 38 & 3.30 & 0.084 & 0.000 \\
\hline Control & 25 & 2.16 & 0.072 & \\
\hline
\end{tabular}

Table 2: TIBC Levels $(\mu \mathrm{g} / \mathrm{dL})$

\begin{tabular}{|l|c|c|c|c|}
\hline Group & N & Mean & Std deviation & P value \\
\hline Patients & \multicolumn{3}{|c|}{0.000} \\
\hline First trimester & 28 & 358.36 & 10.73 & 0.000 \\
\hline Second trimester & 34 & 409.53 & 7.91 & 0.000 \\
\hline Third trimester & 38 & 471.57 & 12.10 & 10.09 \\
\hline Control & 25 & 308.48 & & \\
\hline
\end{tabular}

Table 3: Hemoglobin Levels (mg/dL)

\begin{tabular}{|l|c|c|c|c|}
\hline Group & N & Mean & Std deviation & P value \\
\hline Patients & \multicolumn{5}{|c|}{} \\
\hline First trimester & 28 & 12.15 & 0.27 & 0.1080 \\
\hline Second trimester & 34 & 11.73 & 0.37 & 0.001 \\
\hline Third trimester & 38 & 11.37 & 0.63 & 0.000 \\
\hline Control & 25 & 11.98 & 0.47 & \\
\hline
\end{tabular}

The transferrin levels in the patients during three trimesters and those in controls were studied and were found to be statistically significant in each trimester with $\mathrm{p}$ value of 0.000 . The mean value of transferrin in the patients of first trimester was $2.51 \pm 0.07 \mathrm{~g} / \mathrm{L}$, those in second trimester $2.87 \pm 0.058 \mathrm{~g} / \mathrm{L}$ and third trimester $3.30 \pm 0.084 \mathrm{~g} / \mathrm{L}$, when compared to controls, whose mean value was $2.16 \pm 0.072 \mathrm{~g} / \mathrm{L}$ (Table 1 ). The level of total iron binding capacity progressively 
increased significantly during each trimester. The mean value of total iron binding capacity was $358.36 \pm 10.73 \mu \mathrm{g} / \mathrm{dl}$ in first trimester, $409.53 \pm 7.91 \mu \mathrm{g} / \mathrm{dl}$ in second trimester, $471.57 \pm 12.10 \mu \mathrm{g} / \mathrm{dl}$ in third trimester, whereas the mean value in controls was $308.48+10.09 \mu \mathrm{g} / \mathrm{dl}$ and the $\mathrm{p}$ value $(0.000)$ was statistically significant in all the trimesters (Table 2$)$. The mean value of hemoglobin in the patients in first trimester was $12.15 \pm 0.27 \mathrm{~g} / \mathrm{dl}(\mathrm{p}=0.080)$, second trimester $11.37 \pm 0.63$ $\mathrm{g} / \mathrm{dl}(\mathrm{p}=0.000)$ when compared to the controls with a mean value of $11.98+0.47 \mathrm{~g} / \mathrm{dl}$ (Table 3$)$.

\section{Discussion}

Iron deficiency anemia during pregnancy continues to be a common problem accounting to $40 \%$ of maternal deaths, either directly or indirectly from cardiac failure, hemorrhage or infection, in third world countries. It can also result in an increase in the pre-natal morbidity by increasing the chances for preterm deliveries and intrauterine growth retardation [6,7]. In a normal pregnancy, a woman needs $900 \mathrm{mg}$ of iron for the maintenance of fetus and placenta, red cell expansion and blood loss at delivery. The iron needs of pregnancy have to be met by mobilizing the iron stores from hemoglobin of the circulating red cells. Most women enter pregnancy with little or no iron stores.

The stages of iron deficiency include depleted iron stores at the first earliest stage and are manifested as reduced serum ferritin. Second stage is iron deficiency without clinical anemia, where percentage saturation of transferrin and serum iron decrease, whereas TIBC increases. Iron deficiency is the final stage with low $\mathrm{Hb}$ and red cell indices and a microcytic hypochromic blood smear [15]. Severe anemia even predisposes to infection, particularly during puerperium, increases the risk of thromboembolism and predisposes to decompensation in mothers with cardiac or respiratory disease. It is also an important factor in delayed general physical recovery, especially after caesarean section and women at high parity and or low socioeconomic status [16].

Tranferrin is a glycoprotein, $\beta$ globulin synthesized in liver and carries two atom of iron, in the ferric state. Decreased saturation of transferrin by iron enhances the release of iron from intestinal mucosal cells [8]. In the iron requiring cells, transferrin is taken by transferrin receptor -mediated endocytosis. In antenatal women, due to the elevated steroid levels, the concentration of transferrin increase which represents an increased rate of production for its functional capacities along with no changes in its degradation rate [9]. The clearance time of tranferrin bound iron from circulation is mostly affected by the plasma iron level and activity of erythroid marrow [10]. The serum levels of transferrin where highly elevated in the patients under study in all the three trimesters. The rate of erythropoesis also increases from first to third trimester as the pool of erythroid cells requiring iron increases which leads to progressive decrease in the clearance time of tranferrin from circulation. The mean level of transferrin increased progressively in the present study too from $2.15 \pm 0.074 \mathrm{~g} / \mathrm{L}$ in first trimester to $2.87 \pm 0.058 \mathrm{~g} / \mathrm{L}$ in second trimester and $3.30 \pm 0.084 \mathrm{~g} / \mathrm{L}$ in the third trimester, while in controls the mean value was only $2.16+0.072 \mathrm{~g} / \mathrm{L}$. P value was 0.000 in each trimester showing good statistical significance.

The total iron binding capacity is an indirect measure of the circulating transferrin. When the iron stores become depleted, the serum iron begins to fall and total iron binding capacity increases. Hence, TIBC is a sensitive indicator of early iron store depletion [11]. Raza et al reported increasing levels of serum TIBC throughout pregnancy [12]. In the patients included under this study, the iron binding capacity also increased steadily from first to third trimester, when compared to controls, with a significant $p$ value of 0.000 in all the three trimesters, indicating depleted iron stores.

During the full term pregnancy, the iron requirement amounts to approximately $2.5 \mathrm{mg} /$ day. In third trimester, it rises to 3.0 to $7.5 \mathrm{mg} /$ day. These amounts are greater than those that can be absorbed from even the best diets and stores may be insufficient to meet them. For this reason, early diagnosis of anemia and iron supplementation is frequently, a component of prenatal care. The half clearance time of iron in the presence of iron deficiency is as short as 10 to 15 minutes; this value reflects the limit of iron delivery to the vital organs for metabolism. According to Bengamin et al, iron deficiency anemia was considered to exist during pregnancy, when serum iron level is less than $50 \mu \mathrm{g} / \mathrm{dL}[13]$.

During pregnancy, reduction of hemoglobin level occurs due to plasma volume expansion as a mechanism to improve arterial uterine flow to the placenta [14]. The preferential expansion of plasma volume during pregnancy when compared with red cell volume causes progressive hemodilution up to $30^{\text {th }}$ to $35^{\text {th }}$ week which reduces the hemoglobin concentration to $11 \mathrm{~g} / \mathrm{dL}$ and 
haematocrit to $37 \%$. According to the definition of $\mathrm{WHO}, \mathrm{Hb}$ concentration of less than $11 \mathrm{~g} / \mathrm{dL}$ and a hematocrit of less than $33 \%$ is defined as anemia in pregnancy. The mean value of haemoglobin in the patients of present study decreased gradually throughout the trimesters with a mean value of, $12.15 \pm 0.27 \mathrm{~g} / \mathrm{dL}(\mathrm{p}=0.1080)$ in first trimester , $11.73 \pm 0.37 \mathrm{~g} / \mathrm{dL}(\mathrm{p}=0.001)$ in second trimester, as well as $11.37 \pm 0.63 \mathrm{~g} / \mathrm{dL}(\mathrm{p}=0.000)$ in third trimester, whereas the mean value in controls was only $11.98 \pm 0.047 \mathrm{~g} / \mathrm{dL}$.

\section{Conclusion}

Thus, estimation of serum transferrin can be considered as an early biochemical marker to asses iron deficiency anemia in antenatal women, so that the maternal and foetal, morbidity and mortality can be reduced to a great extent.

\section{Funding: Nil}

Conflict of interest: None.

Permission of IRB: Yes

\section{References}

1. Laboratory indices of nutritional status in pregnancy. National Academy of Sciences.1978,1:164.

2. Bainton DF, Finch CA. The diagnosis of iron deficiency anemia. Am J Med. 1964 Jul;37:62-70.

3. Ann.M, Gronowski. Handbook of Clinical Laboratory Testing During Pregnancy 2004;28: 43.

4. Iron absorption and its implications on strategies to control iron deficiency anemia. ICMR Bulletin 2000 vol 2: 24 .

5. Lynna Y Littleton, Joan Engebretson. Maternal, Neonatal and Women's Health Nursing.2002; 2:202205.
6. Denic S, Agarwal MM. Nutritional iron deficiency: an evolutionary perspective. Nutrition. 2007 JulAug;23(7-8):603-14. Epub 2007 Jun 20.

7. Clark SF. Iron Deficiency Anemia. Nutr Clin Pract.2008; 23(2):128-141.

8. Engmann C, Adanu R, Lu TS, Bose C, Lozoff B. Anemia and iron deficiency in pregnant Ghanaian women from urban areas. Int J Gynaecol Obstet. 2008 Apr;101(1):62-6. Epub 2007 Dec 19.

9. Mendenhall HW. Serum protein concentrations in pregnancy. I. Concentrations in maternal serum. Am J Obstet Gynecol. 1970 Feb 1;106(3):388-99.

10. Brugnara C. Iron deficiency and erythropoiesis: new diagnostic approaches. Clin Chem. 2003 Oct;49(10):1573-8.

11. Hillman Rs Et al: Heamtology in Clinical Practice, $4^{\text {th }}$ ed. New York, Mc Graw .Hill, 2005:631.

12. Raza N, Sarwar I, Munazza B, Ayub M, Suleman M. Assessment of iron deficiency in pregnant women by determining iron status.J Ayub Med Coll Abbottabad. 2011 Apr-Jun;23(2):36-40.

13. Benjamin F, Bassen FA, Meyer LM. Serum levels of folic acid, vitamin B12, and iron in anemia of pregnancy. Am J Obstet Gynecol. 1966 Oct $1 ; 96(3): 310-5$.

14. Mac Gregor M W, Hytten F E, Leitich I. Maternal Factor In Prematurity And Prenatal Mortality Scott Med J 2013:8:126.

15. Clapp I F, Seaward B L, Sleamaker M S \& Hiser J (2008). Maternal Adaptations To Early Human Pregnancy. Am J Obstet Gynecol 159,1456-60.

16. Letsky E. (2009) Haematological disease and pregnancy. In.Chamberlain GVP(ed) Contemporary Obstetrics and Gynaecology London. Northwood publications; pp 95-105.

\section{How to cite this article?}

Stephen S, Samatha P, Transferrin levels in antenatal women. Int J Med Res Rev 2016;4(3):420-423. doi: 10.17511/ijmrr.2016.i03.24 